\title{
Synthesis and Characterization of $\mathrm{Al}_{y} \mathrm{Cu}_{0.15} \mathrm{Zn}_{0.85-\mathrm{y}} \mathrm{Fe}_{2} \mathrm{O}_{4}$ Ferrite Prepared by the Sol-Gel Method
}

\author{
Tagreed M. Al-Saadi ${ }^{1, *}$, Ahmed H.Abed ${ }^{2}$, Ayad Ahmed Salih ${ }^{1}$ \\ ${ }^{1}$ Department of Physics, College of Education for Pure Science Ibn Al Haitham/ \\ University of Baghdad, Baghdad, Iraq \\ ${ }^{2}$ The General Directorate for Education in Diyala, Diyala, Iraq \\ *E-mail: tagreedmm2000@gmail.com
}

doi: $10.20964 / 2018.09 .04$

Received: 3 May 2018 / Accepted: 3 July 2018 / Published: 5 August 2018

Nano powder of zinc ferrite with the chemical formula $\mathrm{Al}_{\mathrm{y}} \mathrm{Cu}_{0.15} \mathrm{Zn}_{0.85-\mathrm{y}} \mathrm{Fe}_{2} \mathrm{O}_{4}(\mathrm{y}=0.15,0.30,0.45$, $0.60,0.75$ ) was synthesized by the sol-gel/auto combustion technique. The average crystallite size was found to be in the range of $28.82-42.27 \mathrm{~nm}$, and the lattice constant decreased from 8.3958 to 8.2966 $\AA$, while the density increased from 5.271 to $5.386 \mathrm{~g} / \mathrm{cm}^{3}$ with increasing Al content. The dielectric loss factor $\left(\varepsilon^{\prime \prime}\right)$, dielectric constant $\left(\varepsilon^{\prime}\right)$ and AC electric conductivity $\left(\sigma_{\text {a.c }}\right)$ were studied, and it was found that $\left(\varepsilon^{\prime}\right)$ and $\left(\varepsilon^{\prime \prime}\right)$ decreased with increasing frequency, while the behavior of conductivity was the opposite. It was also found that there was a variation in the behavior of $\left(\varepsilon^{\prime}\right),\left(\varepsilon^{\prime \prime}\right)$ and $\left(\sigma_{\text {a.c }}\right)$ based on $\mathrm{Al}$ content, and the highest values were found for the sample with an $\mathrm{Al}$ content of $\mathrm{x}=0.3$.

Keywords: Al-Zinc ferrites, Nanoferrite, XRD, SEM, EDX, Dielectric properties.

\section{$\underline{\text { FULL TEXT }}$}

(C) 2018 The Authors. Published by ESG (www.electrochemsci.org). This article is an open access article distributed under the terms and conditions of the Creative Commons Attribution license (http://creativecommons.org/licenses/by/4.0/). 